\title{
Judith Sluiter 1962 - 2018
}

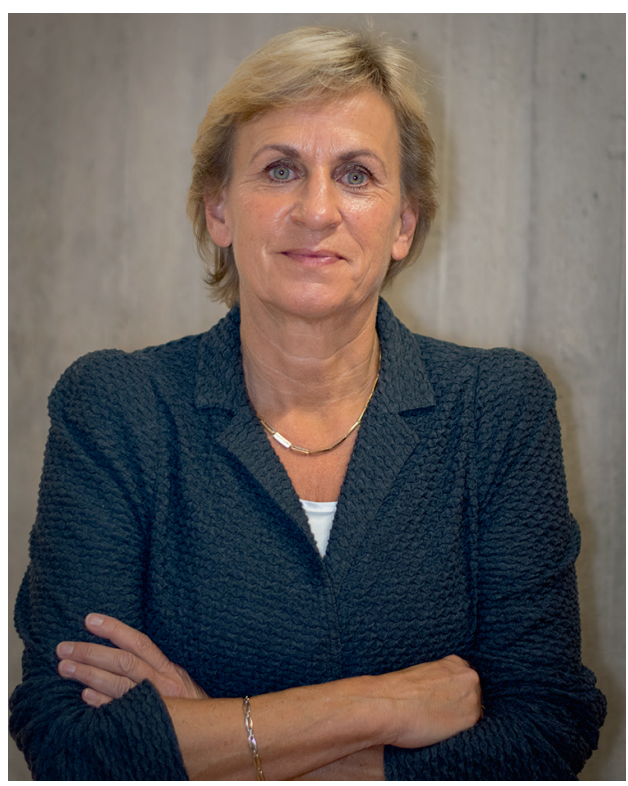

Sinds haar benoeming tot afdelingshoofd van het Coronel Instituut voor Arbeid en Gezondheid bij het AMC in september 2017 maakte Judith Sluiter er een gewoonte van de medewerkers van de afdeling aan het einde van de week een afdelingsinformatiemail met wetenswaardigheden en ontwikkelingen te sturen. De vlak na Pasen gestuurde afdelingsinformatiemail had echter een heel andere inhoud. Daarin stelde ze de medewerkers op de hoogte van het feit dat er in de dagen daarvoor vastgesteld was dat ze ongeneeslijk ziek was. Het bericht sloeg in als een bom.

Judith begon in 1996 bij het Coronel Instituut als onderzoeker op het gebied van werkstress, stresshormonen en vermoeidheid. Waar anderen vaak moeite hebben om een promotietraject in vier tot vijf jaar af te ronden deed zij dat in 3,5 jaar terwijl ze er, op haar verzoek, nog enkele andere projecten naast deed. Onder andere het opstellen van een internationaal veel geciteerd Saltsa Criteriadocument voor werkgebonden aandoeningen van de bovenste ledematen. Het tekent haar tomeloze energie en het enthousiasme die haar hele carrière kenmerken. Na haar promotie in 1999 bleef ze aan het Coronel Instituut verbonden, eerst als postdoc en universitair docent; vanaf 2005 als universitair hoofddocent en vanaf 2007 als Principal Investigator. In 2013 werd ze benoemd tot hoogleraar medische selectie en begeleiding. Vanuit het AMC werd ze in 2016 benoemd tot codirecteur van het in het kader van de aankomende fusie tussen AMC en VUmc opgerichte Amsterdam Public Health research instituut. Vanwege haar vooraanstaande rol in de wetenschap en de maatschappij werd ze in datzelfde jaar benoemd tot lid van de Koninklijke Hollandsche Maatschappij der Wetenschappen (KHMW).

Naast het onderzoek naar werkstress heeft Judith op vele terreinen onderzoek gedaan en geëntameerd, onder andere naar fysiek en mentaal werkvermogen, aandoeningen aan het bewegingsapparaat, veroudering en beroepsziekten. Een deel van haar onderzoek richtte zich op een betere uitvoering van medische keuringen en preventief medisch onderzoek (PMO) door de bedrijfsarts. Op haar initiatief leidde dit in 2009 tot het samen met de NVAB opgerichte Kenniscentrum Medische Keuringen in Arbeid (KMKA). Het beter uiting geven aan de preventieve taak in het werk van de bedrijfsarts was voor haar een belangrijke drijfveer. Ze zou daarover op de BG-dagen van dit jaar een plenaire voordracht houden.

In de weken na het bekend worden van haar ziekte werd duidelijk dat haar lichamelijke toestand snel achteruit ging. "Ik ben in vier maanden tijd dertig jaar ouder geworden", zei ze daar zelf over. Het belette haar niet om zich tot het laatste moment met ongelooflijke energie, moed en humor in te zetten voor haar afdeling en haar mensen. Hoewel ze steeds meer aan huis gebonden was, zette ze een groot deel van haar activiteiten zo lang mogelijk voort en kon iedereen tot op het laatste moment bij haar terecht voor begeleiding, adviezen, tips en hulp, vaak via de telefoon of via e-mail.

Ze was internationaal vermaard en geliefd, zo bleek tijdens het afgelopen ICOH congres in Dublin.

In het weekend van 12 en 13 mei jongstleden, zes weken na het bekend worden van haar ziekte, stuurde ze de laatste afdelingsinformatiemail rond waarin ze bekendmaakte haar werkzaamheden neer te leggen en alle medewerkers bedankte: "Het was een eer om met jullie te werken en te zien hoe jullie je allen inzetten voor onze afdeling en het AMC. Ga alsjeblieft gezamenlijk voort op deze weg en heb vooral veel plezier in de activiteiten die we mogen uitvoeren."

We zijn intens verdrietig om haar overlijden en zullen haar erg missen, maar zijn ook dankbaar dat we zo lang met haar hebben mogen samenwerken.

Monique Frings-Dresen, Carel Hulshof 